\title{
Stability analysis of shafts in the proposed deepening in Zawar Mines, HZL: A Case Study
}

\author{
Rabi Bhusan, Sripad R Naik, Vijay Sekar, K Sudhakar and Aditya Mishra \\ National Institute of Rock Mechanics, \\ Bangalore, India \\ georabi@gmail.com
}

\begin{abstract}
S$ ' factor is very important for operational existence of underground mines i.e. Stability, Stress, Shaft, Stoping and Safety. These factors depend on geology and in situconditions around the excavatedzone. Major geological discontinuities and uncertainties in geology, sometimes have a deleterious effect on the stability and safety of the mine. Therefore, detailed analysis of geological data coupled with stress analysis is necessary before recommending remedial measures. This paper presents the results of $3 D$ numerical modelling and geological studies to assess the stability of four shafts, each of Central Mochia, Balaria, West Mochia and Zawarmala under Zawar group of mines operated by Hindustan Zinc Ltd. (HZL) of Vedanta Group, when deepened by $300 \mathrm{~m}$ from the existing bottom level.Rock Mass Rating (RMR) and Geological Strength Index (GSI) were calculated on the basis of the available data at the mine site. Shafts were modelled using 3D discontinuum software (3DEC) [1] to understand the rock mass behavior and stress distribution around them. Various geological and geotechnical parameters were incorporated into the three dimensional model. Effect of nearby open stopes on the stability of the shaft was also considered in this study. The results showed no sign of abnormal displacement and accumulation of stresses at the existing shaft and the proposed deepened part of the shafts.
\end{abstract}

Keywords-Stability; Shaftsinking; Dolomite; Phyllites; Quartzite; 3D discontinuum modelling

\section{INTRODUCTION}

Zawar mines area comprises of four mines: Central Mochia, West Mochia, Balaria and Zawarmala Mine owned and operated by Hindustan Zinc Ltd. (HZL) of Vedanta Group. Zawar mines area is intensively folded, faulted, foliated and sheared having undulated terrain with low grade metamorphisms.

In recent years, number of mines are working at greater depths (deeper than 300 m) at the Archean Craton Belts such as Singhbhum Craton (Chromite Ore Mine), Dharward Craton (Gold Minerlisation) and Aravalli Belt (Lead Zinc deposits). For continuous production from deep workings a stable shaft is required. Long term stability of the shaft depends on varying stress levels and the adopted support system in the shaft. It also depends on whether the shaft comes under the influence zone of excavated stopes. In this study, four shafts of Central Mochia, Balaria, West Mochia and Zawarmala were studied and were modelled to assess probable effects of deepening of shafts to a further depth of $300 \mathrm{~m}$ was modelled. These mines are located around $45 \mathrm{~km}$ on the southern side from Udaipur, Rajasthan.
Central Mochia:The main service shaft had finished dimension of $5.2 \mathrm{~m} \times 3.8 \mathrm{~m}$ with $300 \mathrm{~mm}$ thick RCC lining and depth of shaft was $457 \mathrm{~m}$. Shaft was located around 250 $m$ south of major subsidence area on the surface. Shaft had steel buntons of size ISBM 300 placed at a spacing of $3.0 \mathrm{~m}$ center to center along the height. Rock bolts of $20 \mathrm{~mm}$ diameter and $1.2 \mathrm{~m}$ length were installed at $1 \mathrm{~m}$ spacing center to center. The shaft was located in fair to good rock mass of greywacke rocks.

Balaria: The mine is accessed through circular shaft of $3.6 \mathrm{~m}$ diameter and a winze below $250 \mathrm{mRL}$. Multiple lens of Balaria mine were divided into eastern and western section acrossthe shaft. Due to inclinedstopes $3 \mathrm{E}$ and $5 \mathrm{E}$ were away from the shaftin the upper level from 378 to 190mRL. Below 190mRL,lenshad approached the shaft pillar boundary below $120 \mathrm{mRL}$, where $3 \mathrm{E}$ lens pass through the shaft. Most of the rock mass is siliceous dolomite/dolomiteand falls under good rock mass category.

West Mochia: The mine is accessed through a rectangular shaft of $3.25 \times 2.9 \mathrm{~m}$ for $158 \mathrm{~m}$ depth $(-452 \mathrm{mRL}$ to $294 \mathrm{mRL}$ )connected witha lined circular shaft of $3.8 \mathrm{~m}$ diameter. Shaft is situated in thefootwall near to the dipping and plunging ore lens of CW0. The ore body had been worked out up to $306 \mathrm{mRL}$ by sub-level open stopping method. It had access through circular shaft ( $5 \mathrm{~m}$ diameter) situated more than $100 \mathrm{~m}$ from the dipping and plunging main ore lens. The transverse sub-level open stoping method was followed by the mine management. The working depth was $173 \mathrm{mRL}$ (570 mRL being the top). The rock disposition is classified as Meta greywacke with an average good rock mass condition.

Zawarmala: Themineis accessed through circular shaft ( $5 \mathrm{~m}$ diameter) situatedmore than $100 \mathrm{~m}$ from the dipping and plunging main ore lens. The transverse sub-level open stoping method was followed by the mine management. The working depth was $173 \mathrm{mRL}$ ( $570 \mathrm{mRL}$ being the top). The major host rock comprises siliceous dolomite and is massive in nature. Near the lens of the ore body, fair to poor rock mass condition was observed.

Mine management envisages deepening of the shaft to a further depth of $300 \mathrm{~m}$ from the present level. The stability of the proposed extension of the existing shaft was studied using three dimensional discontinuum model. Study was conducted using 3DEC, a discontinuum modelling software 
[1]. This paper describes a case study of stress analysis of shafts at four mines of Hindustan Zinc Ltd (HZL) [2].

\section{MethodOLOGY}

Geological plans and sections were used for preparation of 3D geological geometry with different geo-materials. Existing mining conditions were incorporated in the model as close to reality as possible. Stopes in the immediate vicinity of the shafts were also incorporated and simulated in the model. Three-dimensional stress analysis was carried out using Mohr Coulomb elasto-plastic model. Concrete lining and other support elements were also simulated in the model.

\section{GeOlogy AND GEOTECHNICAL ASSESSMENT}

Zawar Mines is the oldest lead zinc mine in India.It is located around $40 \mathrm{~km}$ south of Udaipur, Rajasthan.Zawar mines comprises of four operating mines Central Mochia, Balaria, West Mochia and Zawarmala in the Aravalli super group of Pre-Cambrian age (2.5-2.0 B.Y.) deposits. Stratigraphic succession and tectonic framework, was studied by Ray[3] for Aravalli supergroup in Rajasthan. Present structural disposition of Zawar area is characterized by intense folding, foliations and faultingand ore body width varies from 1 to $40 \mathrm{~m}$. The mineralization is restricted exclusively within dolomitic horizon with few lens of ore body. In Balaria and West Mochia, the ore body is lenticular and plunging.Observations have been made at each approachablelevel with reference to drawing plans at 1:1000 and 1:2000 scales. Shafts wereexcavated in dolomite/quartzite, dolomite and phyllitic schist/greywacke rock. Major portion of the ore body has been extracted and exploration at bottom level is under progress. Since the shaft is lined, geological information from different adit levels were extrapolated to the shaft. Four prominent set of joints were identified in the area. Rock Quality Designation (RQD) was estimated on the basis of Joint Volume (Jv) approach proposed by Palmström [4] (RQD = 115-3.3Jv; Where $\mathrm{Jv}$ is the number of joints per $\mathrm{m}^{3}$ ). Rock Mass Rating (RMR) Bieniawski [5] and Geological Strength Index (GSI) were also estimated in the shaft area.

\section{A. Central Mochia Shaft}

Central Mochia Shaft (CMS)runs from393 mRL (surface) to $-29 \mathrm{mRL}$ (bottom). Geological observations weretaken at 307, 240, 173, 108, 38, 3 and -29 mRL levels (Fig.1). Mafic dyke were marked from the surface to bottom of the mine area.Major rock disposition consisted of highly foliatedMeta greywacke.Ore body wastrending inEast-West direction. Four prominent joints sets J1 $\left(223^{\circ} / 6^{\circ}\right)$, J2 $\left(274^{\circ} / 85^{\circ}\right), \mathrm{J} 3\left(014^{\circ} / 76^{\circ}\right)$ and $\mathrm{J} 4\left(070^{\circ} / 23^{\circ}\right)$ were identified with few random joints. Joint sets, $\mathrm{J} 2$ and $\mathrm{J} 3$ were prominent in the area with higher frequency of occurrence. Subsidence due to stoping was observed on the surface and its effect was seen up to $6^{\text {th }}$ level and below.It was observed that NE and SW corner of the CMS had some cracks in the RCC lining mostly between levels 5 to 7 .

The data was collected below the $5^{\text {th }}$ ( $\left.307 \mathrm{mRL}\right)$ level of the CMS. Drives and cross-cuts in this mine were mostly driven through Meta greywacke, which is very weak in nature. However, at this mine, Meta greywacke was very compact and massive in nature. Here Jv ranges from 9 to 19 , RQD52 to 72 and strike of the vertical foliation varies from $090^{\circ}$ to $270^{\circ}$ around the shaft area. Spacing of foliation varied from $2 \mathrm{~cm}$ to $10 \mathrm{~cm}$. In the 3D model, GSI value of 49 (Fair), RMR value of 57 (Fair), and Uniaxial Compressive Strength (UCS) value of $80 \mathrm{MPa}$ and Modulus of elasticity value of $40 \mathrm{GPa}$ were considered.

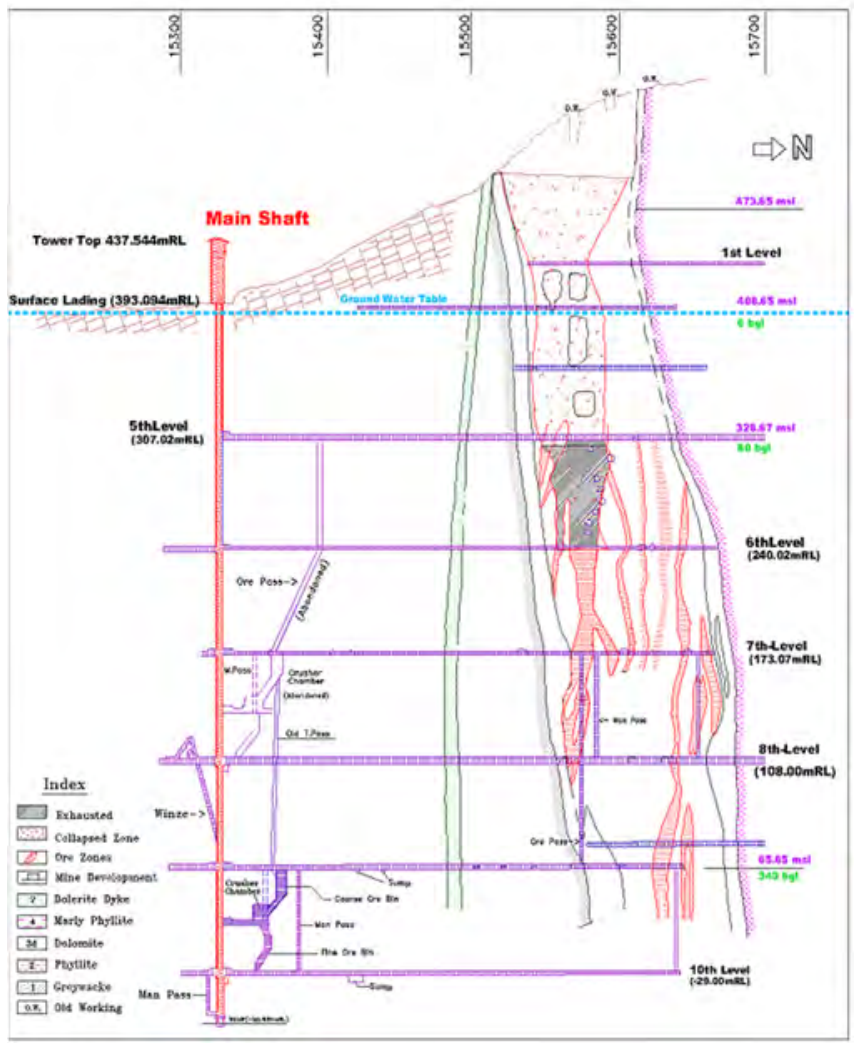

Fig. 1. Geological section of the Central Mochia along with shaft

\section{B. Balaria Shaft}

Balaria Shaft is a circular shaft of dia $3.6 \mathrm{~m}$ from -44 to $394 \mathrm{mRL}$ and is lined below $105 \mathrm{mRL}$. Observations were made at levels $378,250,190,120,105,45,-25$, and -40 $\mathrm{mRL}$ (Fig. 2). The shaft is located in siliceous dolomite which is massive in nature. At Balaria mine, deposits exist in multiple lens on eastern and western side of the shaft. Ore lens $3 \mathrm{E}$ and $5 \mathrm{E}$ were very near to the shaft and plunge $45^{\circ}$ due west. Mining in $3 \mathrm{E}$ has been done till $120 \mathrm{mRL}$ only, while mining in $5 \mathrm{E}$ is still in progress with present workings at $-25 \mathrm{mRL}$. Four prominent jointsets J1 $\left(248^{\circ} / 68^{\circ}\right)$, J2 $\left(313^{\circ} / 87^{\circ}\right), \mathrm{J} 3\left(132^{\circ} / 18^{\circ}\right)$ and $\mathrm{J} 4\left(134^{\circ} / 86^{\circ}\right)$ were identified with two random set of joints. Most of the rock is siliceous dolomite. In the model, four prominent joints were taken with GSI value of 61 (Fair), RMR value of 64 (Fair), and Uniaxial Compressive Strength (UCS) value of $120 \mathrm{MPa}$ and Modulus of elasticity value of $40 \mathrm{GPa}$.

\section{West Mochia Shaft}

West Mochia mine is accessed through a rectangular shaft of $3.25 \times 2.9 \mathrm{~m}$ for $158 \mathrm{~m}$ depth and then a lined circular shaft of $3.8 \mathrm{~m}$ diameter. Shaft is situated in the 
footwall near to the dipping and plunging ore lens of CW0. Ore body was worked out up to $306 \mathrm{mRL}$ by sub-level open stoping method and is dipping $85^{\circ}$ due south. The major rock comprises of Meta greywacke, phyllite and arkosic dolomite which are foliated and fractured at $44 \mathrm{mRL}$. Four prominent sets of joints $\mathrm{J} 1\left(177^{\circ} / 86^{\circ}\right), \mathrm{J} 2\left(253^{\circ} / 20^{\circ}\right)$, J3 $\left(019^{\circ} / 82^{\circ}\right)$ and $\mathrm{J} 4\left(093^{\circ} / 84^{\circ}\right)$ have been identified with two random set of joints.

Area comprises of pure arkosic/siliceous dolomite which is generally strong and competent (RMR 63 to 68, RQD 58 to 65). Siliceous and Phyllitic dolomite were also observed unevenly around the excavated area. The mineralization occurred in multi-lens and width varied from the $1 \mathrm{~m}$ to $20 \mathrm{~m}$ at $70^{\circ}$ to $90^{\circ}$ dip and $045^{\circ}$ dip direction. GSI value of 56 (Fair) and RMR value of 61 were used in the 3D model.

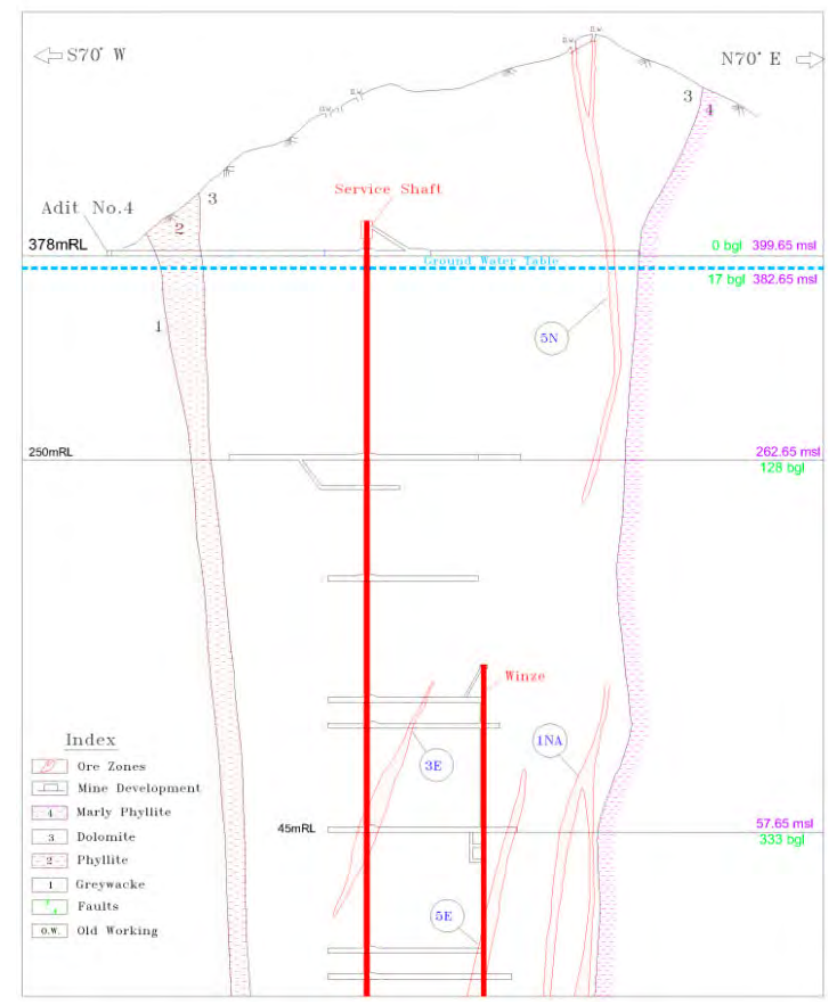

Fig. 2. Geological and shaft section with winz in Balaria Miness

\section{Zawarmala Shafts}

Zawarmala Shaft is a lined circular shaft (diameter $5 \mathrm{~m}$ ) from 466 to $165 \mathrm{mRL}$. Underground observations were taken at levels 433, 355, 300, 250, 225, 200, 173 and 165mRL. The shaft wasexcavated in siliceous dolomite. Four prominent sets of joints $\mathrm{J} 1\left(233^{\circ} / 44^{\circ}\right), \mathrm{J} 2\left(348^{\circ} / 45^{\circ}\right)$, J3 $\left(086^{\circ} / 56^{\circ}\right)$ and $\mathrm{J} 4\left(150^{\circ} / 63^{\circ}\right)$ were identified with two random set of joints.

The pigmatitic and quartz veins wereobserved with highly fractured density and were unevenly distributed. At 200mRL and $173 \mathrm{mRL}$ levels, minor faults were observed around $60 \mathrm{~m}$ away from the mine shaft.The observation were made from the $433 \mathrm{mRL}$ to $173 \mathrm{mRL}$. In the 3D model, GSI value of 61 (Good) and RMR value of 66 (Good) were used.

\section{DiscontinUUM 3D Modelling}

In this study, 3D discontinuum modelling approach was used to understand the stress and displacement distribution around the shafts. 3DEC [1] simulates the response of discontinuous media (such as a jointed rock mass) subjected to either static or dynamic loading. Discontinuum is represented as an assemblage of discrete blocks. Discontinuities are treated as boundary conditions between blocks; large displacements along discontinuities and rotations of blocks are allowed. Individual blocks behave as either rigid or deformable material. Deformable blocks are subdivided into a mesh of finite difference elements, and each element responds according to a prescribed linear or nonlinear stress-strain law. The relative motion of the discontinuities is also governed by linear or nonlinear forcedisplacement relations for movement in both the normal and shear directions.

In this study, the shafts of Central Mochia, Balaria, West Mochia and Zawarmala were modelled using three dimensional discontinuum numerical modelling. The various geological and geotechnical parameters were incorporated. Already extracted stopes where ever applicable were incorporated in the model and effect of stoping operation on the stability of the shafts were studied.Geometrical and geological data for the models were obtained from mine maps, geological mapping in the field and from HZL management.

\section{A. Pre-excavation Stresses}

The following in-situ stresses as given by HZL management was used in the model.

- $\quad$ Vertical Stress $(\mathrm{MPa})=\operatorname{density}(\rho) \times \mathrm{g} \times \operatorname{depth:} \rho=$ 2800 to $3000 \mathrm{~kg} / \mathrm{m} 3$

- Maximum Horizontal Stress $(\mathrm{MPa})=0.048 \times \mathrm{H}+4.4$ $\mathrm{MPa}$; (North - South)

- Minimum Horizontal Stress $(\mathrm{MPa})=0.024 \times \mathrm{H}+2.2$ MPa.(East - West)

\section{B. Rock Properties}

Physico-mechanical properties were provided by HZL management and are listed in Table I.

\section{DISCUSSION OF RESULTS}

\section{A. Central Mochia shaft}

In the model, the shaft was deepened with same rectangular section from $-59 \mathrm{mRL}$ to $-359 \mathrm{mRL}(300 \mathrm{~m})$. Lining was provided in the deepened portion. The displacementcontour in a vertical section through the shaft after deepening is shown in Fig. 3 and in a horizontal section through the shaft at $300 \mathrm{mRL}$ in Fig.4. Itindicates that the southern wall of the subsidence area shows large displacement values $(10-23 \mathrm{~mm})$ near the surface. However, the displacement at the shaft reduces to $8-10 \mathrm{~mm}$ up to 5 th level from shaft top and diminishes with depth.The stress distribution in the shaft lining is shown in Fig.5. It may be noted that the stress distributions are as per the excavations in the surrounding areas and there is no abnormality of stresses surrounding the shaft. The probable reason for 
bending of shaft buntons, shearing and bulging of lining is due to stress concentrations in the corners particularly in the $\mathrm{NE}$ and SW corners. The deepened shaft section was also analyzed with circular section. It may be noted that the circular section offers more uniform distributionof stressesand displacements in the liner and also in the surrounding rock mass.

TABLE I. PhySICO-MECHANICAL PROPERTIES

\begin{tabular}{|c|c|c|c|c|}
\hline $\begin{array}{l}\text { Sl. } \\
\text { No. }\end{array}$ & Properties & $\begin{array}{l}\text { Dolomite/ } \\
\text { ore body }\end{array}$ & $\begin{array}{l}\text { Quartzitic } \\
\text { Dolomite }\end{array}$ & $\begin{array}{l}\text { Phyllite/ } \\
\text { greywack } \\
\text { e }\end{array}$ \\
\hline 1 & Density, $\mathrm{kg} / \mathrm{m}^{3}$ & 3000 & 3000 & 2800 \\
\hline 2 & UCS, $(\mathrm{MPa})$ & 120 & 135 & $80-100$ \\
\hline 3 & $\begin{array}{c}\text { Young Modulus, } \\
(\mathrm{GPa})\end{array}$ & 40 & 40 & $30 / 35$ \\
\hline 4 & Poisson ratio & 0.25 & 0.25 & 0.25 \\
\hline 5. & Friction Angle & $30^{0}$ & $30^{0}$ & $30^{0}$ \\
\hline
\end{tabular}

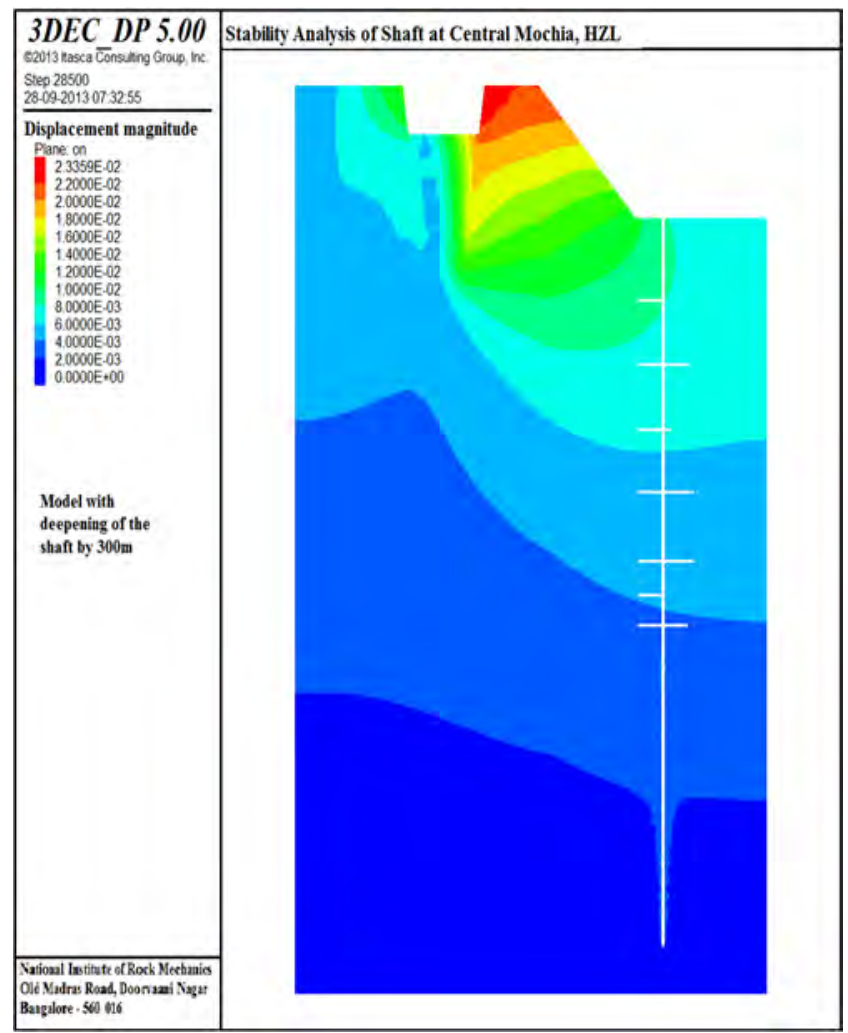

Fig. 3. Displacement pattern in a vertical section through the Shaft after deepening, Central Mochia, HZL

\section{B. Balaria Shaft}

3D Model showing the location of the shaft with different material with same circular section from $-50 \mathrm{mRL}$ to $-350 \mathrm{mRL}(300 \mathrm{~m})$ is shown in Fig.6. Shaft was excavated to the present depth with lining and the effect of stopes in the vicinity of the shaft viz, 3E (up to $120 \mathrm{mRL}$ ) and 5E (up to $-25 \mathrm{mRL}$ ) was analyzed. The adjacent open stopes were also incorporated during the study.

Displacement at $0 \mathrm{mRL}$ around the shaft and excavated stopes is shown in Fig.7. Displacement magnitudes with the deepening of the shaft is depicted in Fig.8. It may be noted that the stress distributions are as per the excavations in the surrounding areas and there is no abnormality of stresses surrounding the shaft. Lining was provided in the deepened portion. The displacement pattern after deepening is also analyzed. There are no abnormal stresses and displacements surrounding the shaft after deepening.

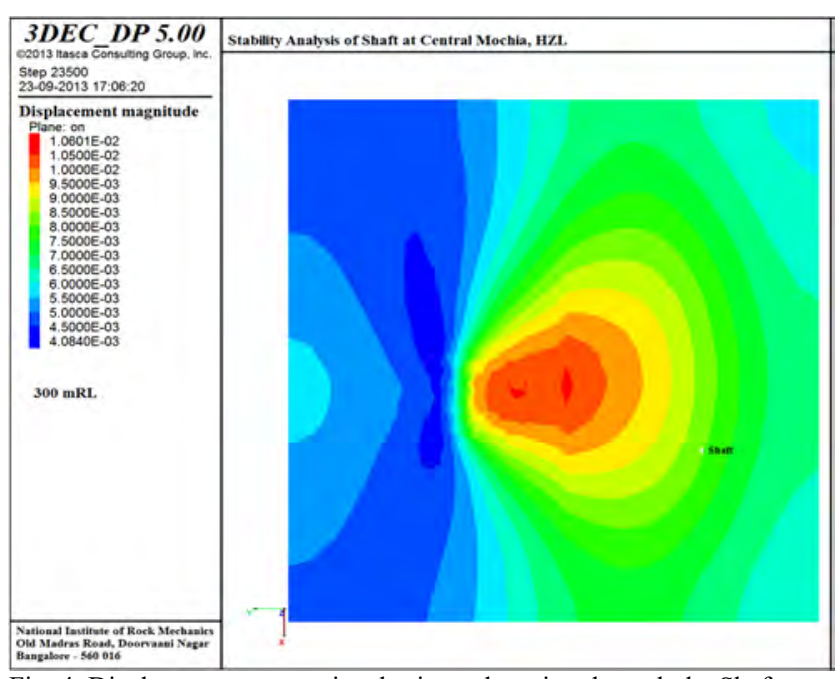

Fig. 4. Displacement pattern in a horizontal section through the Shaft at 300mRL Central Mochia, HZL

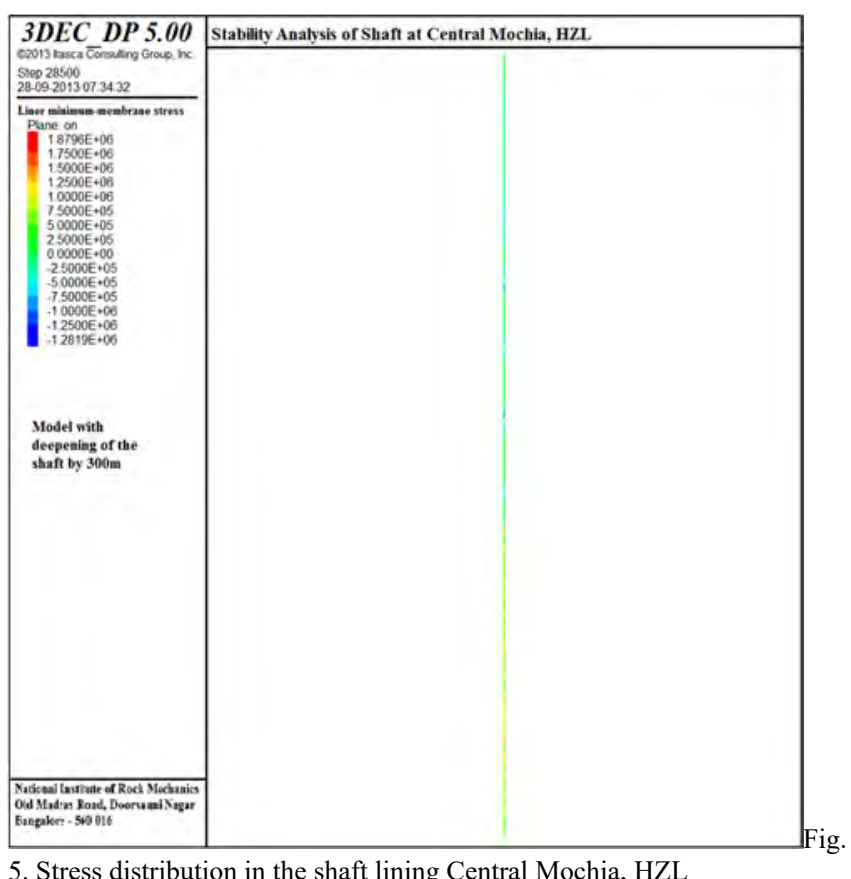

lining Central Mochia, HZL

\section{West Mochia Shaft}

West Mochia is accessed through a rectangular shaft $3.25 \times 2.9 \mathrm{~m}$ upto $158 \mathrm{~m}$ depth ( $-452 \mathrm{mRL}$ to $294 \mathrm{mRL})$ and then a lined circular shaft of $3.8 \mathrm{~m}$ diameter. The shaft is situated in the footwall near to the dipping and plunging ore lens of CW0. The ore body has been worked out up to 306 mRL by sub-level open stopping method. The stability of existing shaft was evaluated and feasibility of deepening the shaft by another $300 \mathrm{~m}$ was also studied. 3D model was 
prepared using geological plans and sections and stoped out workings were also modelled as shown in Fig.9.

Displacements at various levels were studied and displacement contours at $100 \mathrm{mRL}$ is shown in the Fig. 10. The shaft was excavated further $300 \mathrm{~m}$ with same circular section from $25 \mathrm{mRL}$ to $-275 \mathrm{mRL}$.Fig. 11 shows a vertical section showing the distribution of displacement with the deepening of the shaft. It may be noted that the stress distributions are as per the excavation in the surrounding areas and there is no abnormal stresses and displacements surrounding the shaft after deepening. Lining was provided in the deepened portion. The stress distribution in the lining after deepening of the shaft is shown in Fig. 12.

\section{Zawarmala Shaft}

3D Model Zawarmala showing the location of the shaft is shown in Fig.13. Circular shaft ( $5 \mathrm{~m}$ dia) is situated at a distance of more than $100 \mathrm{~m}$ from the dipping and plunging main ore lens. The ore lens is being worked out by transverse sub-level open stoping method. The present working depth is $173 \mathrm{mRL}$ (570 mRL being the top). Shaft was excavated to the present depth with lining and the effect of stopes in the vicinity of the shaft viz, 3E (up to $120 \mathrm{mRL}$ ) and 5E (up to $-25 \mathrm{mRL}$ ) was analyzed.

The displacement pattern observed through the vertical section is shown in Fig. 14. Displacement pattern at 300mRL is shown in Fig.15 and it can be seen that maximum displacement of $1.6 \mathrm{~mm}$ would occur at this location. Displacement vectors and velocity vectors through the vertical section is shown in Fig. 16.

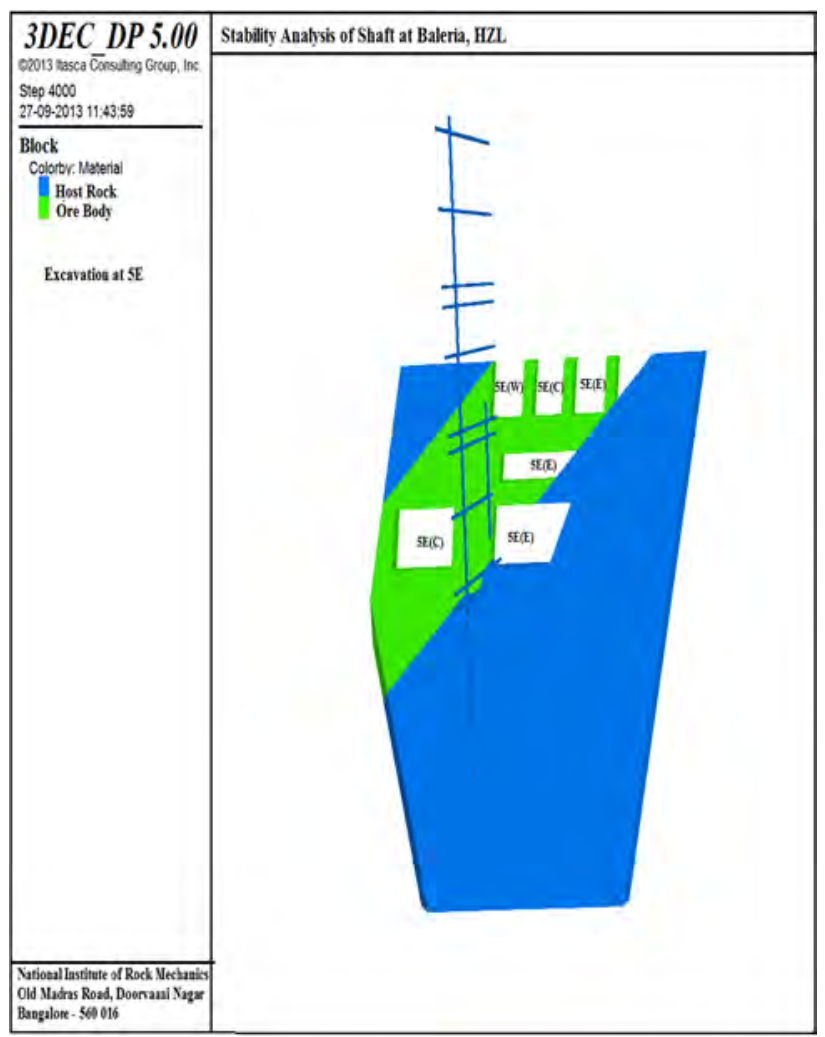

Fig. 6. Model showing the location of the shaft with different material in Balaria Mine, HZL
In the model, the shaft was deepened with same circular section from $165 \mathrm{mRL}$ to $-135 \mathrm{mRL}(300 \mathrm{~m})$. Lining was provided in the deepened portion. There is no abnormal stresses and displacements surrounding the shaft after deepening. The stress distribution in the lining is shown in Fig. 17.

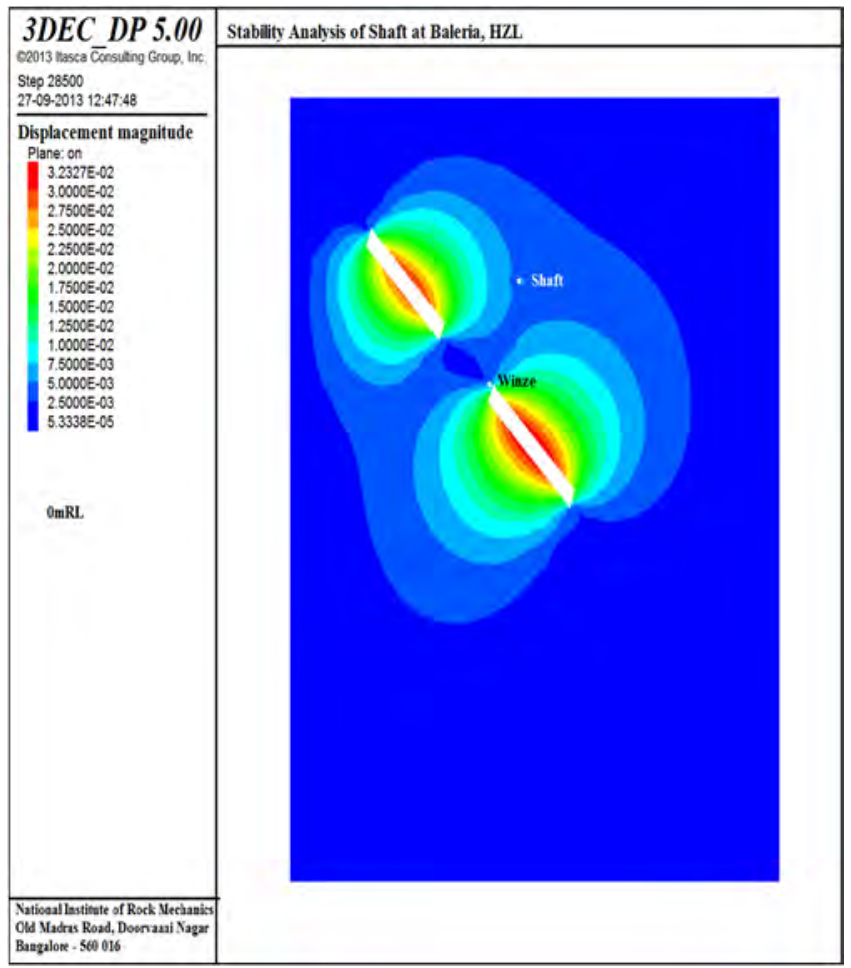

Fig. 7. Displacement pattern at $0 \mathrm{mRL}$ at Balaria Mine, HZL

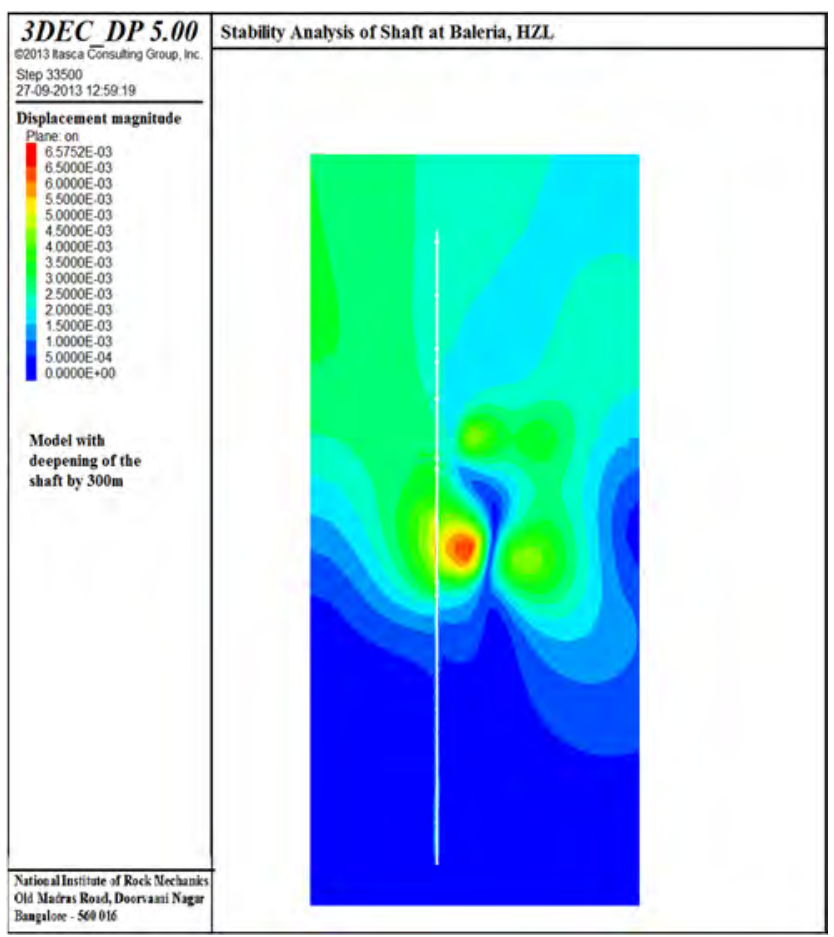

Fig. 8. Displacement pattern with deepening of the shaft at Balaria Mine, HZL 


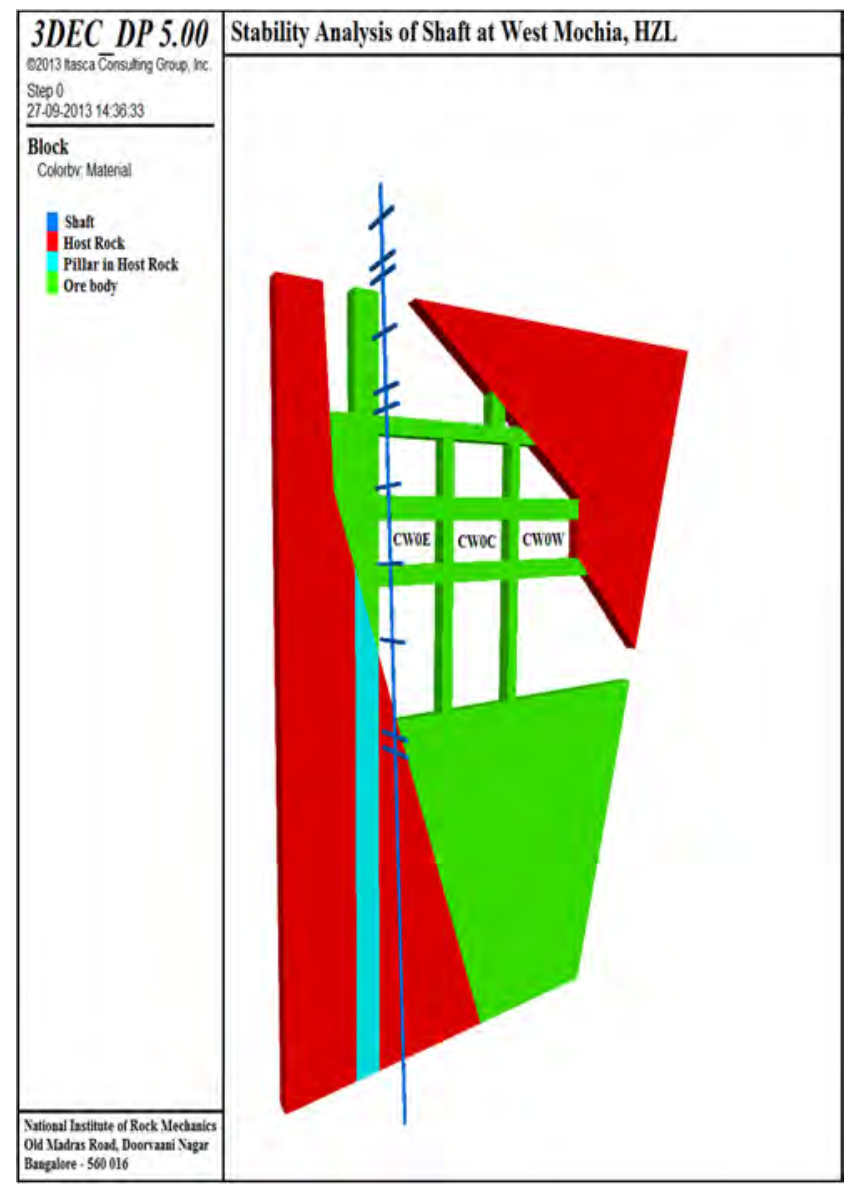

Fig. 9. Model showing the location of the shaft with different geomaterial material West Mochia Mine, HZL

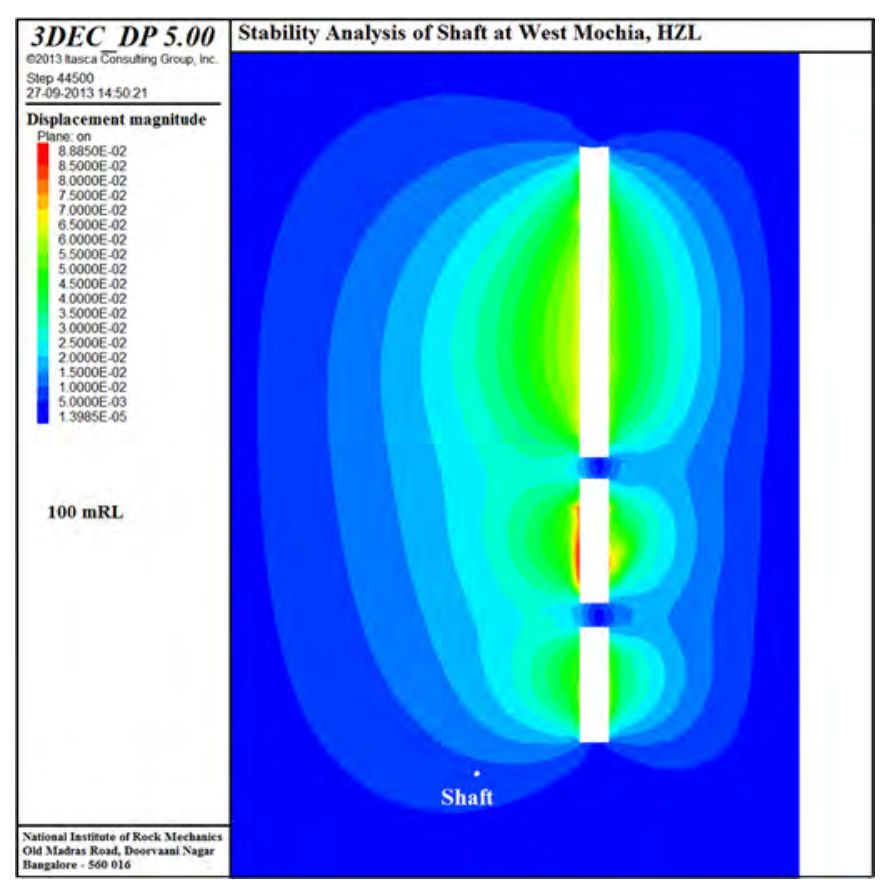

Fig. 10. Model showing horizontal displacement at 100mRL West Mochia Mines, HZL

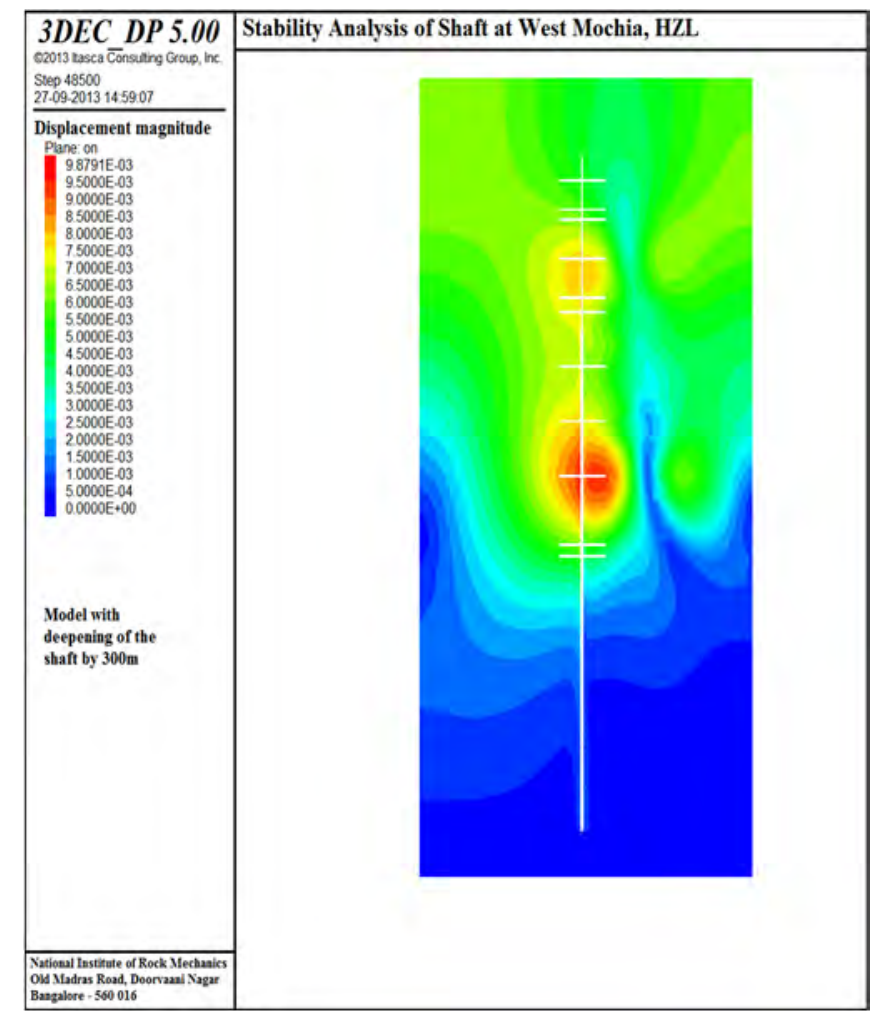

Fig. 11. Model showing displacement along the vertical section West Mochia Mines, HZL

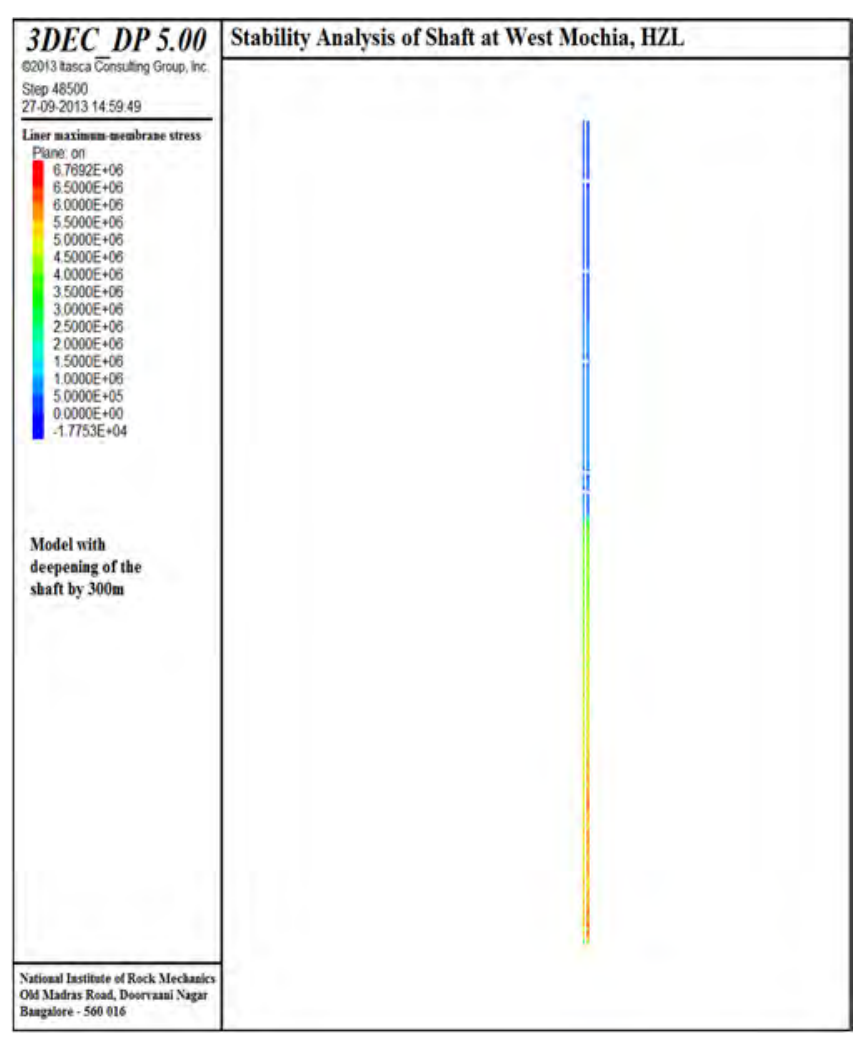

Fig. 12.Stress distribution in the lining after deepening of the shaft is shown West Mochia Mines, HZL 


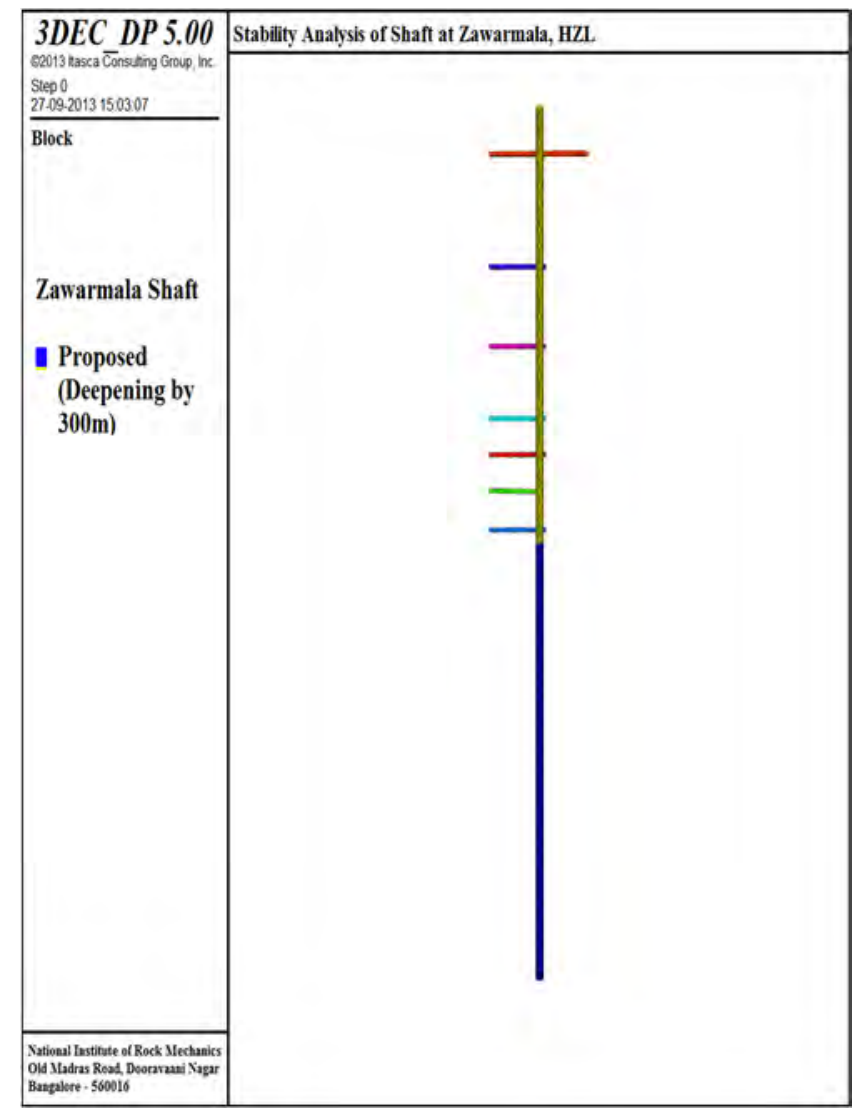

Fig.13. Model showing the location of the shaft at different level Zawarmala Mines, HZL

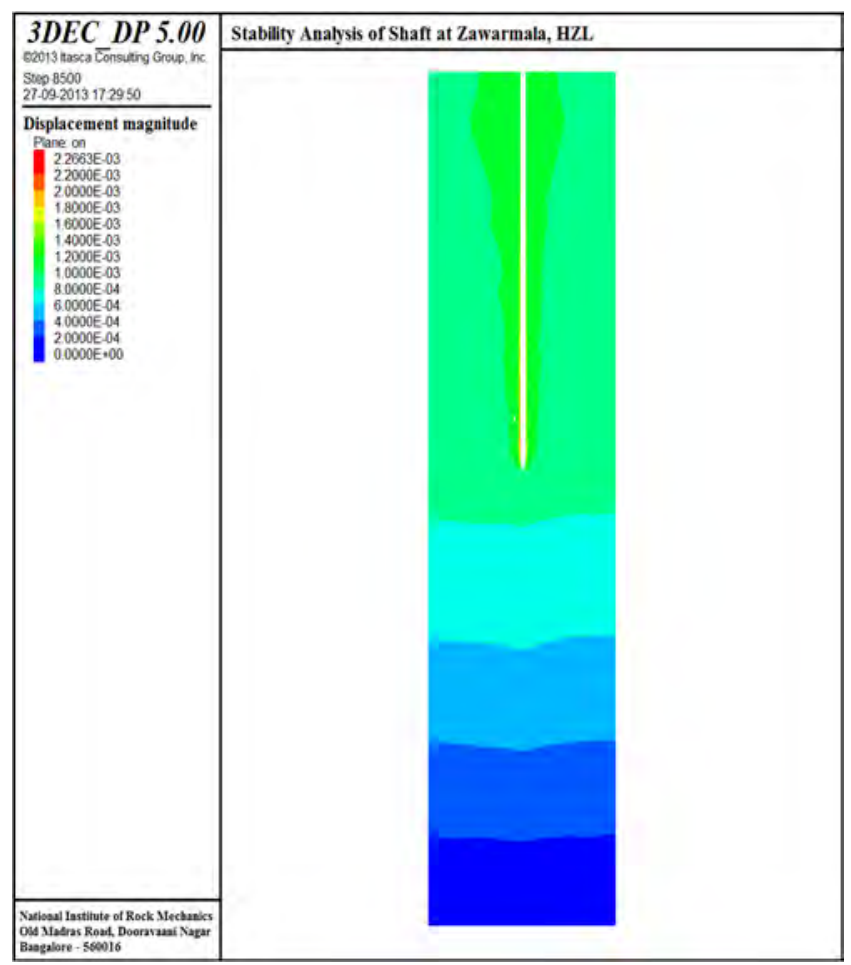

Fig. 14. Model showing displacement along the vertical section Zawarmala Mines, HZL

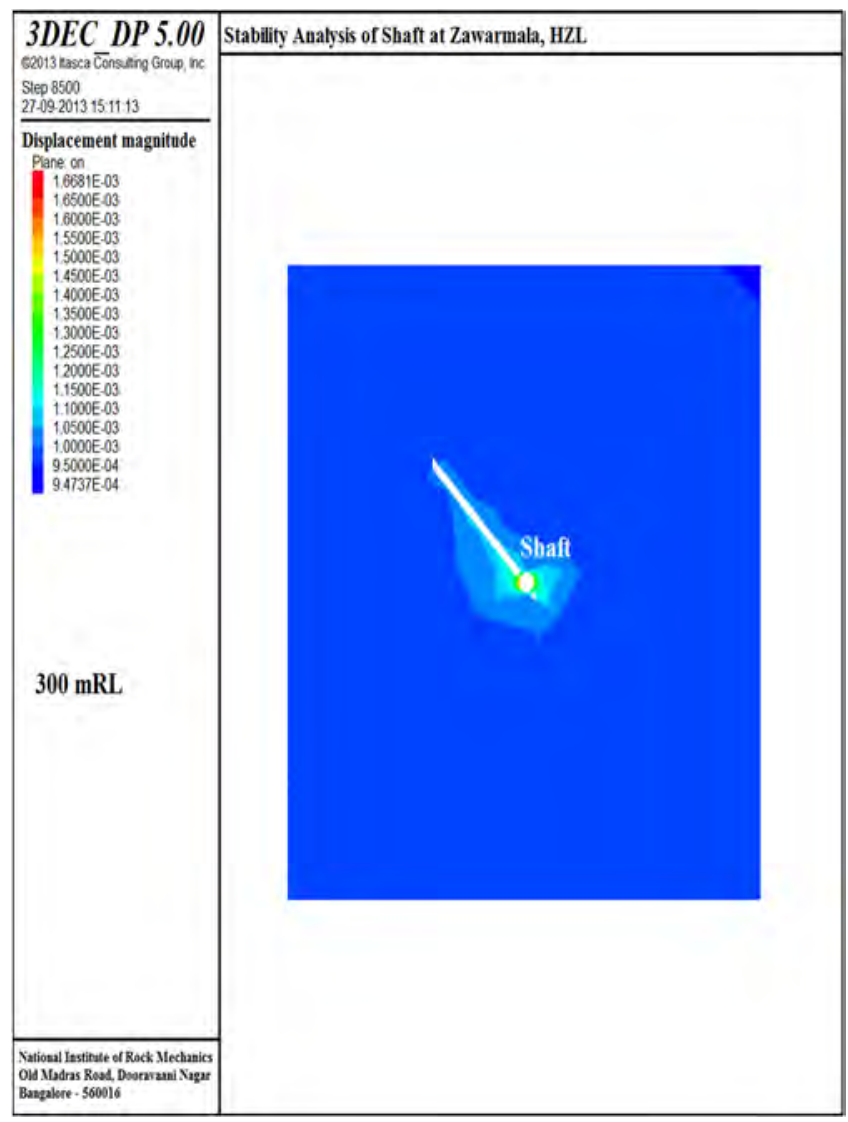

Fig. 15. Model showing displacement along the horizontal at $300 \mathrm{mRL}$ section Zawarmala Mines, HZL

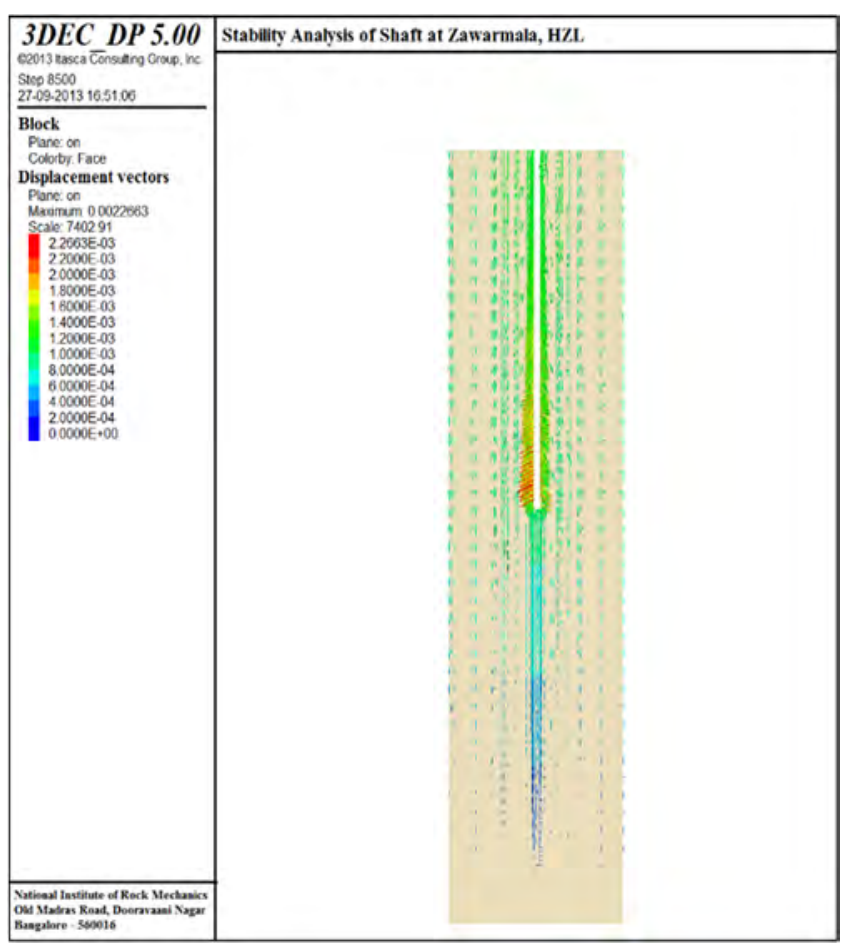

Fig. 16. Model showing displacement vectors and velocity vectors through the vertical section at Zawarmala Mine, HZL. 


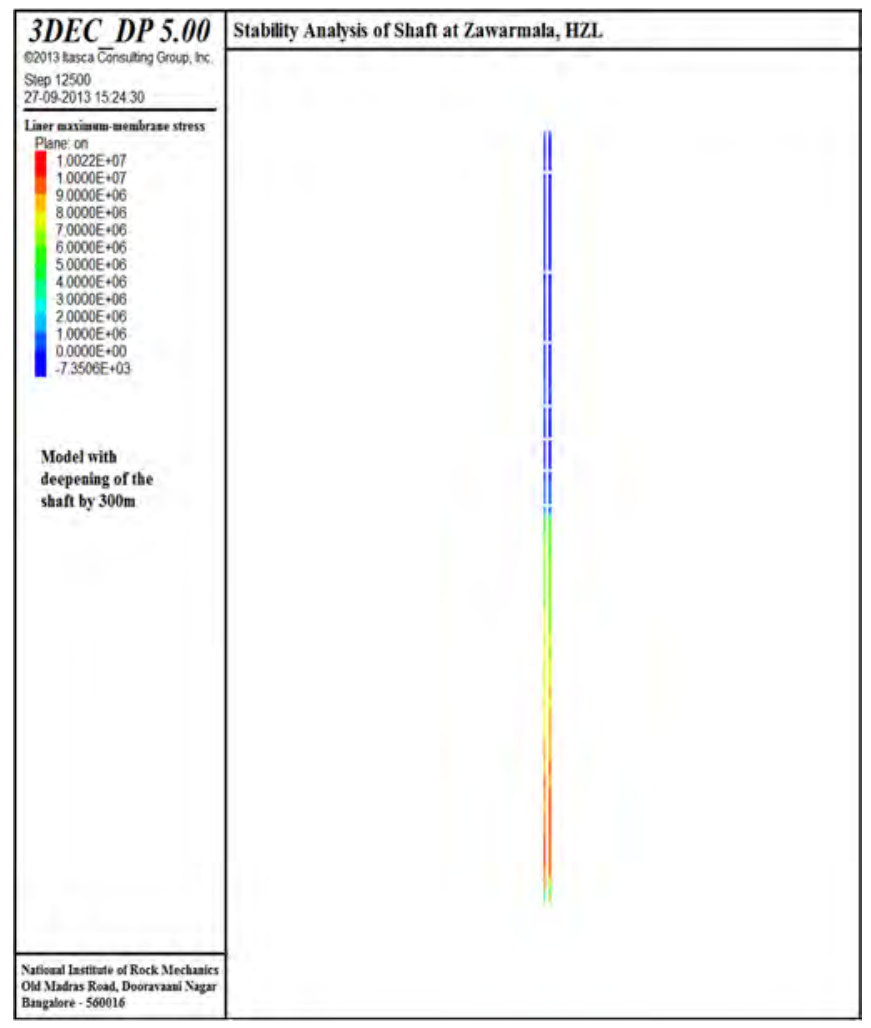

Fig.17 Model showing liner stress at circularshaft of Zawarmala Mine HZL

\section{CONCLUSIONS}

At central Mochia, results of 3D stress analysis of the shaft and the effect of the nearby workings and the subsidence indicates that currently the shaft is not affected by the subsidence and the associated caving of the surrounding old workings up to 5th level. However, if the pillars at deeper levels fail and leads to further subsidence in a wider area, then the shaft is likely to be affected. This warrants design of proper stoping parameters (stope dimension, drilling and blasting). In order to ensure proper ground control around the shaft, lens within perimeter of $200-250 \mathrm{~m}$ may be back filled. Analysis of deepening of the shafts with rectangular section and circular section shows that circular section is preferred as it offers better distribution of stresses and displacements surrounding the shaft. Hence it is recommended to deepen the shaft with a circular section.

At Balaria, currently the shaft is not affected by the stoping operations. However, the 5E stope between 38 to $25 \mathrm{mRL}$ may be back filled keeping in view of the long term stability of the shaft. Analysis of deepening of the shafts with circular section shows that there is no abnormal stresses and displacements surrounding the shaft after deepening. Shaft may be deepened up to $-350 \mathrm{mRL}$ with current dimensions.

At West Mochia, currently the shaft is not affected by the stoping operations. However, during mining CW0 (E) between 192 and $132 \mathrm{mRL}$ proper measures to be taken to minimise excessive breakage/wall rock failure.
At Zawarmala, since the shaft is located away from the main ore lens and gradual shifting of the ore lens due to plunge, possibility of stoping operations affecting the shaft are remote. Analysis of deepening of the shafts with circular section shows that there is no abnormal stresses and displacements surrounding the shaft after deepening. Shaft may be deepened up to $-135 \mathrm{mRL}$ with current dimensions.

\section{REFERENCES}

[1] Anon,. 3DEC Version 5 Manual. Itasca Consulting Group, Inc. USA., 2013.

[2] Sripad, R. N., Nair, R., Bhusan, R., Renaldy, A., and Sudhakar, K. Stability anlysis of Shaft at Central Mochia, Balaria, West Mochia and Zawarmala mines of Hindustan Zinc Ltd. NIRM Report submitted to HZL. pp73, 2014

[3] Roy A.B, Stratigraphy and tectonic framework of the Arvalli Mountain Range in Ray A.B. Precambrian of Arvalli Mountain Rajsthan. India, Memoires Geological Scoiety of India v.7 p 3-31, 1988.

[4] Palmström, A. The volumetric joint count - a useful and simple measure of the degree of rock jointing. Proc. 4th congr. Int. Assn Engng Geol., Delhi 5, 221-228, 1982.

[5] Bieniawski, Z.T. Engineering rock mass classifications. New York: Wiley, 1989 